\title{
Community Participation in the Activities of Improving Food Security Through the Climate Village Program in the Madukoro Village Kajoran District Magelang
}

\author{
Sriyanto ${ }^{1, *}$ Qurrota A'yuni Saniya² \\ 1,2 Universitas Negeri Semarang \\ "Corresponding author. Email: sriyantogeo@mail.unnes.ac.id
}

\begin{abstract}
This paper was to find out the forms of activities in increasing food endurance through the climate village program in Madukoro Village and to analyze the effect of community participation in increasing food endurance through the climate village program in Madukoro Village. The samples in this study were 70 members of the Reksobantolo farmer group. The methods of data collection used were questionnaires, interviews, observation, and documentation. The data analysis techniques used were descriptive analysis and simple linear regression. The results of this research are: 1) Madukoro Village has carried out many activities as an effort to improve food endurance, including polyculture and monoculture planting patterns, the application of rainfed irrigation system and local irrigation system, integrated agriculture, diversification of food plants with fruits and vegetables and the use of the yard by making fish ponds and planting live pharmacy plants. One of the activities of the influential is integrated agriculture which became the leading activity in Madukoro Village because it successfully combines and organizes agriculture, animal husbandry, and fisheries activities. 2) Community participation in increasing food endurance in Madukoro Village is high with an average score of 55.55 from a maximum value of 80 . The results of simple linear regression analysis indicate that the participation of the farmer group affects increasing food endurance with a coefficient value of 0.024 . Labor participation is the highest participation and goods participation is the lowest type of participation. It shows that the climate village program has a positive impact on society so that community involvement is high. Assistance from related agencies still needs to be continued so that the community can develop their ideas and skills. This shows the climate farm program has had a positive impact that the community feels so that involvement of the participation of the community is high.
\end{abstract}

Keywords: Food Security., Climate Village Program, Madukoro Village.

\section{INTRODUCTION}

Climate change has impacted most communities, but people are less aware of the change. The incidence of flood, drought, landslide, high wave, and the increase of seawater advance is increasingly common with increasing intensity, resulting in casualties, economic (crop-and-failure) and ecology is the impact of climate change. Climate change is no longer a speculative issue and the fact of its impact affects millions of people around the world, negatively impacting their efforts to get out of poverty[3].

The Indonesian Government in presidential regulation number 61 the year 2011 on national
Action Plan for Greenhouse Gas emission reduction (RAN-GRK) to face current climate change, conducted a participatory approach of the central government, local governments, and related parties to develop the regional action plan for Greenhouse Gas emission reduction (RAD-GRK) in the efforts to achieve GHG emissions reduction targets in all parts of Indonesia[1]. The climate of the village Program comes as an innovation from the government in providing an understanding of the impacts of climate change and the adaptation and mitigation efforts that target communities at the local level. The program of Climate Village (Proklim) as the follow-up efforts of RAN-GRK and RAD-GRK is a community-based program with a national scope developed by the Ministry of Environment and Forestry to encourage 
the active participation of communities and all parties to carry out local actions in the face of climate change impacts and greenhouse gas emission reduction efforts. Food production is heavily influenced by temperature increase, rainfall pattern change, and intensity of flood exposure and drought in an area[2]. Description of activities that can be performed by the community in the framework of the climate Village program in the form of adaptation efforts to the impacts of climate change can be implemented through many activities including the improvement of food security with activities such as the application of polyclinic and monoculture planting pattern system, application of irrigation systems, integrated agriculture by combining agriculture with farms and fisheries, the management of food crops fruits and vegetables and the use of yardland by planting the plant of live pharmacies and making fish ponds. Sriyanto (2019)[5] Food security became one of the indicators of adaptation of the community in overcoming global warming according to government Regulation No. 19/2012. Sastroputro (1988) in Saptorini (2003:23)[6] states the level of community participation is influenced by development programs, socio-economic conditions of the Community, and environmental physical conditions of the environment. Socio-economic conditions include the level of education, income, culture, and social strata in the Community system. Hamijoyo (2007) in Sulistiyorini, et al. (2015:74)[7] outlines the types of participation, namely the participation of thought, energy, money, skills, and goods. The dryland conditions and low rainfall in the village of Madukoro cause the public to have efforts to adapt climate change mitigation and mitigations, related to drought disasters that occur for the sustainability of food security in the region. Prevention is done with various activities one of them increased food security. In 2016 Madukoro received an award from KLHK (Ministry of Environment and Forestry) because of its success in managing the environment so that Madukoro Village received the PROKLIM award. The purpose of this study is to know the forms of activities in improving food security through the Climate Village program in Madukoro and analyzing the influence of public participation on the improvement of food security through a climate village program in Madukoro village.

\section{RESEARCH METHOD}

The research is located in the village of the Madukoro Kajoran District of Magelang Regency. As a population, the community is a member of Madukoro village, which is joined by a farmer group Reksobantolo as many as 70 people. Research using nonprobability sampling techniques. The tools and techniques used are interviews, observations, polls, and documentation. The analytical techniques used in this study are quantitative descriptive analysis, descriptive statistics, and simple linear regression.

\section{RESULT AND DISCUSSION \\ 3.1.General conditions of the village Madukoro}

The astronomic village of Madukoro lies at $110^{\circ}$ 04 ' 11 " $-110^{\circ} 05^{\prime} 46^{\prime \prime} \mathrm{SL}$ and $07^{\circ} 31^{\prime} 55^{\prime \prime}-07^{\circ} 32^{\prime}$ 08" EL. Administratively, Madukoro Village is bordered by other regions that include the north bordered by the village of Sambak District Kajoran, in the south bordered by Kaliabu Village, Salaman Subdistrict, bordered by Bumiayu Village, Kajoran Subdistrict and the West borders Kwaderan Village Kajoran District. Madukoro Village is located $20 \mathrm{~km}$ southwest of Magelang Regency and $6 \mathrm{~km}$ from Kajoran district. The village of Madukoro consists of 5 regions.

The village of Madukoro is a village that has been creating autonomy in the field of food, because of its community ability to fulfill its own food needs by powering the natural resources owned, so that in 2011 was chosen to become replica Demapan (Desa Mapan Pangan) built by the village of Wonogiri who had been awarded the food independent village in 2007 along with Sambak village In 2016, Madukoro was again awarded a National Proklim Award for his success in conducting adaptation and mitigation activities in climate change, especially in the activities of increasing food security.

The village of Madukoro is located south of Mount Sumbing with a height of 500 masl which is a major medium-plain typology in the range of 400 to 700 above sea level, so the average air temperature ranges from $30^{\circ}$ per day. The amount of rainfall is detected as much as $286.9 \mathrm{~mm}$ per year with 6 months spread, so the number of rainy seasons and dry season in Madukoro village is relatively balanced annually.

The village of Madukoro has an area of 45 ha consisting of 25 hectares of forest and 27 ha for settlements, paddy fields, and freshwater pools. The potentials of Madukoro village are farmland, livestock, and fisheries. The people's forest is managed agroforestry by combining timber plants with HHBK plants (non-timber forest products) and crops under the crop and green crops or livestock food, which previously were in the forest areas of the original people in the form of Moor (dryland) that are planted only cassava. The village of Madukoro is also passed by the flow of river Kali Butek with a length of 2000 meters, the river Kaliurang with a length of 1500 
meters, and the Balong River with a length of 1000 meters.

\subsection{Improvement of Food Security Activities Through The Climate Village Program in Madukoro Village}

\subsubsection{Planting Pattern System}

The planting pattern system applied in the village of Madukoro is a polyclinic and monoculture system. The Polyculture plant uses an intercropping planting pattern where the planting is carried out in the same period time. In the village of Madukoro cassava and corn plants are planted in the same period, then pasted together with the banana plant. The monoculture system in the village of Madukoro is specially intended for rice crops because rice is still the main commodity of foodstuffs. System of planting patterns applied in Madukoro village as in Figure 1.

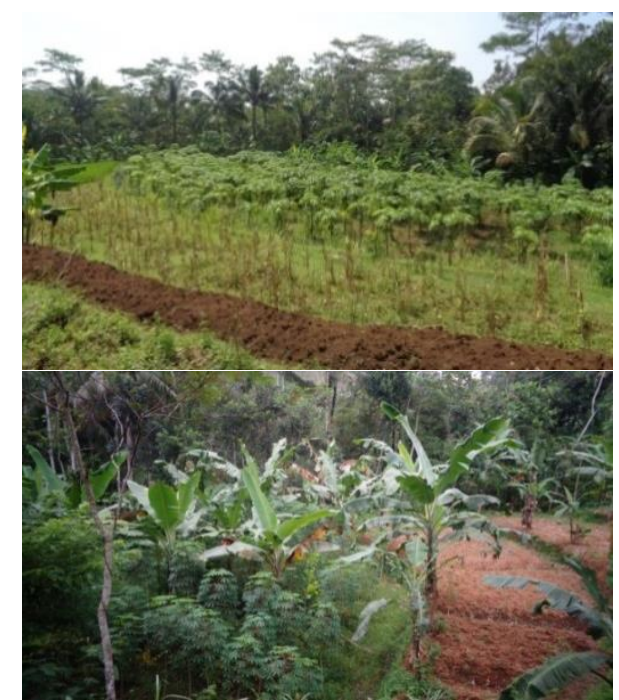

Figure 1. Intercropping System in Madukoro Village

\subsubsection{Irrigation system}

The irrigation system uses a rain-water irrigation system, and also some irrigation comes from the local irrigated system of springs and streams flowing around the farmland. In addition to the use of paddy fields, the rice field is also used to bury the pond of fish around the rice fields in Madukoro village. This is due to the lack of water availability, so the selection of irrigation systems is very important in addition to the selection of planting commodities.

\subsubsection{Integrated farming}

The village of Madukoro has combined fishery and farming activities in one land. Mr. Gunaji as an integrated farming community figure says that integrated farming is enabled to optimize all potential resources. Integrated farming is expected to suppress the month of agricultural waste. Its main objective is to have a direct reciprocal relationship between biotic and abiotic environments in agricultural land ecosystems (Figure.2).

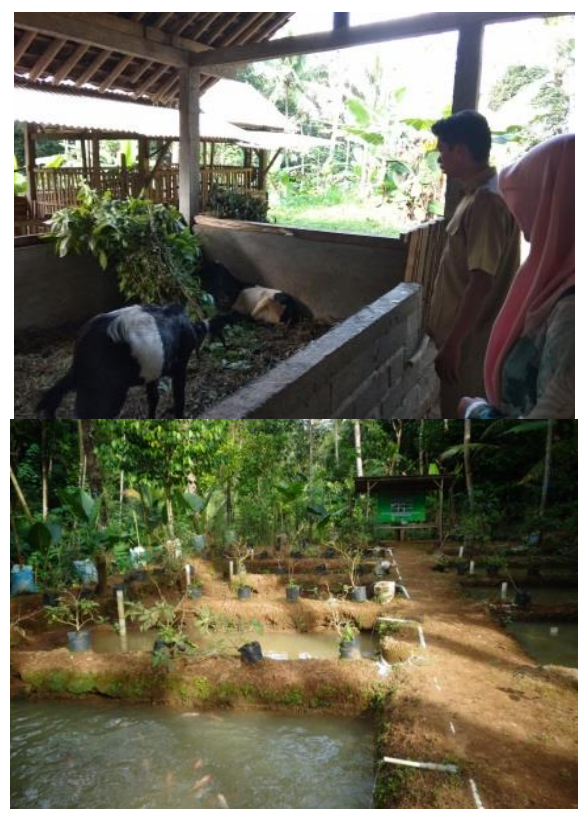

Figure 2. Integrated Farming in Madukoro Village

\subsubsection{Variety of food crops}

The variety of food plants consist of fruit crops such as papaya, banana, jackfruit, watermelon, coconut. Various types of vegetables such as long beans, chili peppers, and also live pharmacy plants (fig. 3). The plants are cultivated in yard land around the house and the garden. Not relying on only one foodstuff but trying to cultivate a variety of food crops. With this, the need for food materials can be fulfilled and the community can save spending.

\subsubsection{Land Utilization Yard}

Madukoro Village uses yard land as a place to grow living pharmacy plant, vegetables using polybag, then there are also make use of making a fish pond in front of the map, other than that there are making cage to keep chicken. The main factor that led to the public in the village of Madukoro planting crops is to ensure the availability of various food ingredients continuously and also improve the fulfillment of family nutrition. 


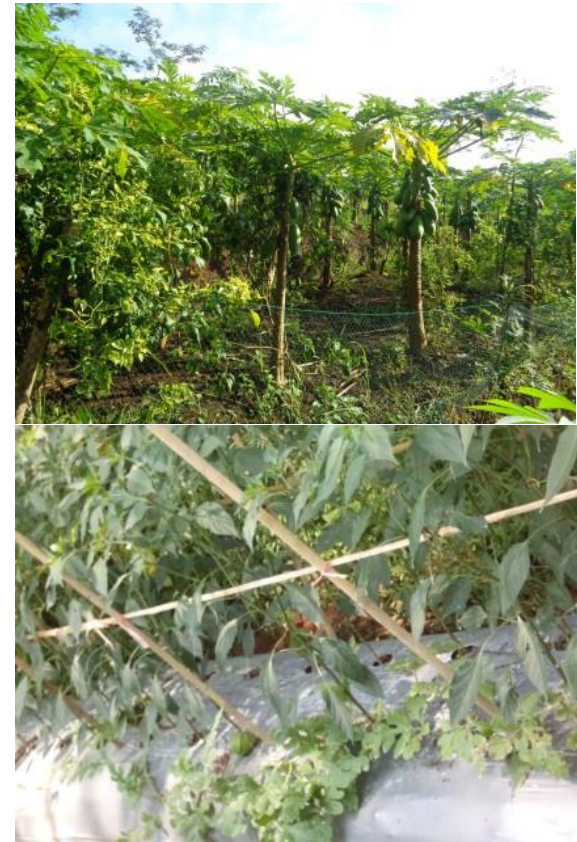

Figure 3. Plant varieties cultivated in Madukoro Village

\subsubsection{Community-based education}

In this research, there is a non-formal educational material that is accepted by the people of Madukoro village especially the group of farmers Reksobantolo among them with a form of socialization activities, counseling, and training conducted by related offices such as DLH (environment agency), Bappeda (regional development planning agency), BPK, and the livestock and Fisheries office.

\subsection{Community participation in the Climate village Program of Madukoro}

Based on the results of the processing poll using a statistical method with the help of Microsoft Excel application 2010, indicating that the minimum answer score of the respondent is 35 . The respondent's maximum answer score was 77 . The score is obtained by summing the total score and then searching for the minimum value and maximum value achieved. Total is 3889 and then divided by all total respondents is 175 so that the average score is 55.55. The form of community participation in the village of Madukoro includes the participation of thinking, skills, energy, goods, and money.

Table 1. Community Participation Level Criteria

\begin{tabular}{lll}
\hline Interval Score & Percent $(\%)$ & Criteria \\
\hline $66-80$ & $81.25-100$ & Very High \\
$50-65$ & $62.50-<81.25$ & High \\
$35-49$ & $43.75-<62.50$ & Low \\
$20-34$ & $25.00-<43.75$ & Very Low \\
\hline
\end{tabular}

The highest community participation is in the form of power participation with a score of 233, the participation of money with a score of 208.5, the participation of skills with a score of 196.5, thought participation with a score of 177 , and the lowest participation in the form of goods participation 168.5.

Participation in the form of energy includes the community that follows the work of the service in the development of infrastructure for the improvement of food security, such as following service work in mutual assistance in building roads to facilitate accessibility on villages. Participation in the form of money includes community participation in donating money for development in improving food security, especially in agricultural activities. Participation in the form of skills includes community participation in agricultural cultivation and the type of food crops. Participation in the form of goods includes community participation in contributing agricultural facilities and equipment necessary to improve food security. The participation of thinking includes community participation in contributing ideas, presenting ideas in deliberations, and giving innovation in the improvement of food security.

\subsubsection{Increased food security activities through the climate village Program in Madukoro}

Based on the results of the poll given to 70 members of the farmer group Reksobantolo showed that the activities of the climate Village program in the increase of food security is high. Based on the results of the processing of polls using the statistical method with the help of Microsoft Excel application 2010, indicating that the minimum answer score of the respondent is 23 . The respondent's maximum answer score was 39 . Based on the table of food security score criteria, the interval of 26,0-33,5 score indicates high criteria. The average result of the score is 33.08 which indicates that the average level of food security in Madukoro is high.

Table 2. Scoring Criteria for Food Security Activity Level

\begin{tabular}{lll}
\hline Interval Score & Percentage $(\%)$ & Criteria \\
\hline $34.0-40.0$ & $>81.25$ & Very High \\
$26.0-33.0$ & $62.50-81.25$ & High \\
$18.0-25.0$ & $43.75-62.40$ & Low \\
$10.0-17.0$ & $<43.75$ & Very Low \\
\hline
\end{tabular}

The merger of agricultural activities, livestock, and fisheries became one of the solutions for the improvement of land productivity, environmental conservation, and integrated Village development, thereby improving the welfare of the people with more income. The management of land undertaken by farmers can utilize waste to be processed into products 
that sell one of the only compost fertilizers produced from the rest of organic materials derived from plants, animals, and other materials. Another factor that supports the improvement of food security in Hamlet Madukoro 02 is the ability of food crops despite its contribution is not as much as other activities, due to some things, there are still many people who are more dependent on the staple food of grain, lack of interest in the creation of food crops, and also the lack of public knowledge about the creation of food crops using other crops such as vegetables, fruits and so on.

\subsubsection{Influence of Community Participation on Improving Food Security Through The Climate Village Program}

The value of 31.759 means that if there is no $\mathrm{X}$ value (community participation) then the value of $\mathrm{Y}$ value consistency (food security) is 31.759 . The value of 0.024 is a regression coefficient number. This figure implies that with each addition of $1 \%$ of a community participation rate $(\mathrm{x})$ then food security will increase by 0.024 . The regression coefficient is positive, so it can be said that the directional effect of variable $\mathrm{x}$ to variable $\mathrm{y}$ is positive. So the equation Regresinya is $\mathrm{Y}=31.759+0,024 \mathrm{X}$. Based on the significant value of the coefficient table obtained the significance value of 0.000 , for the value of the calculated $\mathrm{t}$ greater than $\mathrm{T}$ table is $15,752>1,667$ so it can be declared that the variable $\mathrm{x}$ (community participation) affects the variable $y$ (food security).

Based on the results of the research in Hamlet Madukoro 02 showed that community participation is influential on increasing food security in the Climate Village program, the community was formed by the group to be able to cope with the food demand. Participation is driven by health awareness and dietary shifts due to the influence of climate change and the variety of community activities. Another factor that encouraged the public participation of Dusun Madukoro 02 against the desire for improvement of food security is the availability of land resources that are increasingly reduced to the height of land utilization competition between the food sector with the non-food sector.

\section{CONCLUSION}

The activities of increasing food security through the climate Village program that has been conducted in the village of Madukoro are the application of polyclinic and monoculture planting patterns, application of irrigation systems, integrated agriculture by combining agriculture with livestock and fisheries, the management of food crops fruits and vegetables and the use of yardland by planting plant pharmacies live, and the manufacture of fish ponds. Public participation in the increase of food security through the Climate Village program in the village of Madukoro is high with an average score of 55.55. This shows the climate farm program has had a positive impact that the community feels so that involvement of the participation of the community is high.

\section{REFERENCES}

[1] Bappenas. 2011. Program Kampung Iklim Sebagai Upaya Tindak Lanjut RAD-GRK. http//www.bappenas.go.id/ ProgramKampung-Iklim-Sebagai-Upaya Tindak-LanjutRAD-GRK/. Diakses 15 Oktober 2018.

[2] Lobell, D. B., A. Sibley, dan J.I. Ortiz Monasterio. 2012. Extreme Heat Effects on Wheat Senescence in India. Nature Climate Change. 2 ( 3), pp.186-189.

[3] Omwenga, Jusper Maranga, Paul Omondi, dan Fatuma Daudi. 2019. Ecosystem-based Adaptation to Climate Change - Policy Making and Institutional Framework in Kenya's Mt. Elgon Forest Ecosystem. International Journal of Environment and Climate Change. 9 (12), pp.682-690. ISSN. 2581-8627.

[4] Putri, I.M., 2019. Partisipasi Masyarakat Dalam Pelaksanaan Program Kampung Iklim Di Dusun Soka Desa Lerep Kecamatan Ungaran Barat Kabupaten Semarang Tahun 2019. Edu Geography, 7(1), pp.1-9.

[5] Sriyanto, E.K. and Maulana, M.A., 2019. Adaptation Pattern of Lerep Village as Thematic Climate Program in Dealing with Global Warming. In Proceedings of the 1 st International Conference on Environment and Sustainability Issues, ICESI 2019, 18-19 July 2019, Semarang, Central Java, Indonesia

[6] Saptorini. 2003. Persepsi dan Partisipasi Masyarakat dalam Pelaksanaan Konservasi Hutan Mangrove di Kecamatan Sayung Kabupaten Demak. Tesis. Semarang: Universitas Diponegoro.

[7] Sulistiyorini, Nur Rahmawati, Rudi Saprudin Darwis, dan Arie Surya Gutama. 2015. Partisipasi Masyarakat dalam Pengelolaan Sampah di Lingkungan Margaluyu Kelurahan Cicurug. Share Social Work Jurnal. 5 (1), pp. 71-80. ISSN. 2339-0042. 